\title{
Causes of Involuntary Unemployment in Brazil
}

\author{
Domingos Isaias Maia Amorim ${ }^{1}$, Jair Andrade de Araujo ${ }^{2}$, Francisco José Silva Tabosa ${ }^{2}$, Ahmad Saeed Khan ${ }^{2}$, \\ Maria Josiell Nascimento da Silva ${ }^{1}$ \& Pablo Urano de Carvalho Castelar ${ }^{3}$ \\ ${ }^{1}$ Graduate Student at the Masters Program in Agricultural Economics, Federal University of Ceará (UFC), Brazil \\ ${ }^{2}$ Professor at the Post-Graduate Program of the Agricultural Economics Department, Federal University of \\ Ceará (UFC), Brazil \\ ${ }^{3}$ Professor at the Finance Course of the Federal University of Ceará (UFC), Brazil \\ Correspondence: Domingos Isaias Maia Amorim, Federal University of Ceará (UFC). Av. Mister Hull, 2977 - \\ Campus do Pici, Bloco 826, Fortaleza - Ceará, CEP 60.440-970, Brazil. Tel: 55-85-3366-9716. E-mail: \\ domingos_isaias@hotmail.com
}

Received: May 2, 2019

Accepted: May 30, 2019

Online Published: June 10, 2019

doi:10.5539/ijef.v11n7p75

URL: https://doi.org/10.5539/ijef.v11n7p75

\begin{abstract}
Unemployment has been approached in research focusing on macroeconomic aspects, but from the microeconomic perspective, the literature is still recent. The objective of this work is to analyze the determinants of involuntary unemployment in Brazil. Thus, a Logit model is applied to data from the 2015 National Household Sample Survey (PNAD). Among the results, we find that younger individuals, living in rural areas, which have less education, tend to be more in involuntary unemployment. Also, analyzing the marginal effects of race and marital status, non-white and/or unmarried individuals are more likely to be unemployed, suggesting possible discrimination.
\end{abstract}

Keywords: job market, involuntary unemployment, Brazil

\section{Introduction}

Unemployment is one of the most concerning issues of an economy, a phenomenon of great importance, since both the weakening of job creation and the dismissal of employed individuals usually trigger other problems for society. From the macroeconomic point of view, most models focus on involuntary unemployment by relating it to answers in the standard model of the labor supply. Examples include Bargain et al. (2014), Blundell and Shephard (2012), Keane and Moffitt (1998) and Van Soest (1995). In reality, demand-side constraints may limit these sets of discrete options, when considering the possibility that individuals or families may not be able to gain employment as they are trying to provide work for companies (Bargain et al., 2010).

As for the economy, the greater the unemployment rate, the higher the government's unemployment insurance costs, not to mention the opportunity cost of the income that those unemployed individuals would be generating for the country's economy if they had wages to consume goods and services. To the individual, unemployment leads, in many cases, according to Alvaro (1992), to problems of stress, depression and low self-esteem. In addition, one of the worst consequences for the individual is the loss of knowledge and skills previously acquired, leading to a divestiture in human capital.

In conceptual terms, the Brazilian Institute of Geography and Statistics (Instituto Brasileiro de Geografia $e$ Estatística - IBGE) considers as being unemployed any person aged 16 years old or more who, during the week in which the research occurred, took measures to look for work or who sought to establish himself or herself in a job during the previous week (MOCCHON and TROSTER, 1994), but the possibility of someone who is 14 years old or more that wants to participate in the job market as an apprentice is also considered, according to what is allowed by the Brazilian Statute of the Child and the Adolescent (Estatuto da Criança e do Adolescente - ECA).

According to traditional economic theory, there are three types of unemployment which can be distinguished by their generating mechanisms. Following Rainho (2014), there is frictional (or transitional) unemployment, which occurs because of imperfect information, as well as the lack of visibility and transparency in the job market. Seasonal unemployment, which is marked by the variation in the supply and demand of labor for a given cycle, 
for example, within the agricultural field, where at certain periods of the year the labor supply is greater, when a decrease in unemployment can be observed. And involuntary unemployment (also called structural or conjectural unemployment), which can be considered the most severe type of unemployment, defined by a mismatch between supply and demand for labor, with workers being available on the market, but there are no jobs, thus generating an imbalance. In this work, involuntary unemployment is the research focus.

Kato and Ponchirolli (2002) point to the increase in unemployment in Brazil from the mid-1990s to structural, conjunctural and seasonal factors. As for structural factors, issues such as low economic growth, insufficient education and inflexible legislation, can be considered as directly or indirectly responsible for the low qualification of the workforce in Brazil, evidencing that many of the problems such as unemployment in the country are generated by the low qualification of the existent labor force, stemming from a precarious and insufficient education.

It should be noted that, as companies modernize and increase the complexity of the technology used, greater technical and personal skills are required and, therefore, people are frequently considered to be unqualified for open positions in companies, if the schooling system does not provide adequate levels of education.

The contribution of this work consists in presenting the microeconomic factors that determine if the individual is unemployed involuntarily, and why different groups of individuals in the same country are affected in unequal ways, based on data from the 2015 National Household Sample Survey (Pesquisa Nacional por Amostra de Domicílio - PNAD) for Brazil, considering the country as a whole, as well as separately analyzing the rural and urban areas for robustness, since the rural areas have specificities which must be taken into account.

To achieve this objective, we use a logistic regression model. In order to present greater robustness and to adequately choose the appropriate model, some tests were performed, among them, the Hosmer-Lemeshow Goodness-of-fit test, the likelihood ratio test, and the Receiver Operating Characteristic (ROC) curve.

This work is divided into four sections, in addition to this introduction. Each section addresses the following aspects: Section 2 presents the theoretical and empirical evidence on unemployment. Section 3 presents the methodology and the econometric model. The results are discussed in section 4. Lastly, in section 5, the concluding remarks are presented.

\section{Theoretical and Empirical Evidence on Unemployment}

In a country of continental size, such as Brazil, changes in the unemployment scenario can affect different groups of the population in very different ways, indicating the heterogeneity of the effects that cause such unemployment. The discrepancy between groups leads economists and other scholars to wonder what are the factors that actually determine or influence changes in the level of unemployment.

The literature features several works carried out on the subject, pointing most frequently to explanations based on macroeconomic factors, such as the growth level of the country's GDP, the intensification of technological progress and changes in the rate of inflation.

Layard, Nickell, and Jackman (1991), for instance, argue that the unemployment issue is complex and driven by several factors, besides macroeconomic and conjunctural factors. The authors question whether the attitude of the unemployed in the search for employment is an important factor and, for example, whether the characteristics of these people who are looking for a job is what will determine their success in the search. Thus, the authors' contribution to the theory of unemployment is the search for the explanation of this phenomenon through the personal attributes of those who are in the job market looking for occupation.

Considering individual attributes, the role of schooling, seen as an investment in human capital, seems to positively affect the probability of the individual finding a job, and presents a positive correlation with the average remuneration of the worker, according to some authors. For Becker (1975), for example, investment in education, training and courses are considered investments in human capital, as they increase the individual's lifelong gain. The author also warns that new technological advances can be of little value, if only a few skilled workers exist in the country (or region) to take advantage of that technology. Thus, economic growth depends on a cohesive relationship between knowledge and human capital.

Kingdon and Knight (2004) conducted a study for South Africa, a country with some of the highest unemployment rates in the world. The authors first presented a picture of the distribution of unemployment in South Africa, asking who the unemployed in the country are. Then, they identified the characteristics that make a person more likely to be unemployed. Through descriptive statistics and the estimation of a logit equation of unemployment, the authors show that certain groups are considerably more likely to enter and remain in unemployment than other groups, and also present evidence that rural unemployment rates are greater than the 
unemployment rates in the urban areas. Baah-Boateng (2013) seems to partly corroborate these results while studying Ghana, observing that the groups that suffer the most vulnerability to unemployment are composed of young people and urban dwellers, with educational factors and gender explaining unemployment in some particular cases.

In Brazil, up until the mid-1990s, unemployment was one of the main concerns of Brazilians due to the high level of unemployment and high discrimination of minorities in the job market, causing several authors to carry out research on the subject during the period, as well as in the early 2000s. Rossi and Oliveira (2015), for instance, point out that, among the several structural factors that influence unemployment, insufficient education is one of the most critical points in the country, being relatively straightforward to conclude that many issues, such as unemployment in the country, are generated by the low qualification of the existent human capital, originating from a precarious and insufficient education.

Sampaio (2012) investigates the transactions that occur in the job market in the South region of Brazil, considering employees, the unemployed and individuals who were out of the job market between 1995 and 2005 . The econometric model used was the Multinomial Logit model applied using PNAD microdata. The author concludes that there is a positive and decreasing relationship between age and the probability of being employed, and a negative and decreasing relationship between age and the possibility of being out of the job market.

Fernandes, Lima, and Santos (2008) argue that the unemployment rate in Brazil affects different social groups in an unbalanced manner, as well as different segments of the labor force. The authors used data from the 2005 PNAD and also the Multinomial Logit model, finding that unemployment rates are greater for women who are up to 24 years old than for those in other age groups. In addition, younger individuals with children are less likely to be employed, thereby increasing their probability of unemployment.

Mendonça, Lima, and Lírio (2009) use a similar approach, studying the job market for women between 15 and 24 years of age in the Brazilian Northeast region, based on data from the 2006 PNAD. As a result, the authors find that work experience, level of schooling, level of income and the existence of children are the explanatory variables with greater significance in the model. Research conducted by Santos, Leal, and Fernandes (2010) for the state of Minas Gerais, for example, corroborates the findings of Fernandes, Lima, and Santos (2011). Also using a multinomial logit model for data from the 2005 PNAD, the authors show that young women up to 24 years of age have a higher rate of unemployment than other age groups and same age.

Investigating the individual attributes in the age range between 16 and 29 years old in 2007, Cunha, Araujo, and Lima (2011) point out that young people who are females, non-white, less educated and who are a spouse in a family household, are more likely to be unemployed.

In a more recent work, Araújo and Antigo (2016) analyze unemployment in Brazil from 2002 to 2011 using data compiled by the IBGE. The authors also use a multinomial logit model for the analysis, as well as a univariate study of transition matrices applied to microeconomic aspects. The results found that variables such as sex, role in the family, age and education have are a significant influence on a person's success finding a job. Furthermore, the higher the level of education a worker has, the lower the influence of the aforementioned variables on the success of this worker's job search. Also, those workers considered to be semi-qualified are the most sensitive to the influence of said traits on their chances of employment.

As for involuntary unemployment itself, one of the pioneering works is that of Lindbeck and Snower (1987), where the authors present a theory which seeks to explain why unemployed workers, called outsiders, are unable (or unwilling) to find jobs, even when prepared to work for less than those already employed, called insiders. The authors analyze both the possibility of a macroeconomic and microeconomic equilibrium through an intertemporal model, and concur that the main reason for involuntary unemployment is that it is costly for firms to substitute outsiders for insiders, and that insiders manage to capture at least some of the associated economic rent in the process of wage determination.

In recent times, the issue has been discussed in the literature using structural models of labor supply, as presented by Boer (2015), who makes a structural analysis of labor supply considering involuntary unemployment in the Netherlands, where it was concluded that the average elasticity of labor supply is slightly lower in the model considering involuntary unemployment, than in the model which does not consider it.

Another approach uses a New Keynesian framework, such as Christiano, Trabandt, and Walentin (2010), which integrates unemployment into a DSGE model, relating fluctuations in consumption with unemployment, focusing particularly on scenarios of economic recession.

However, the use of involuntary unemployment in this present work follows another approach, using it as an 
object of research in order to capture the microeconomic constraints that end up generating involuntary unemployment in Brazil.

\section{Methodology}

\subsection{Data}

The information used in this work comes from the microdata of the National Survey of Household Sample (Pesquisa Nacional de Amostra Por Domicílio - PNAD), made available by the Brazilian Institute of Geography and Statistics (Instituto Brasileiro de Geografia e Estatística - IBGE) for 2015 (Note 1).

The PNAD adopts a stratified and conglomerate sampling plan with one, two or three stages of selection, depending on the stratum. For the empirical analysis, the sample will be expanded using the weight of the individual, which are the weights of the sample units provided in the microdata files, which are incorporated into the analysis using the weighting options. For Silva, Pessoa, and Lila (2002), when calculating the weights of the sample units, the estimates obtained for the corresponding population parameters are not biased, thus not using these weights would imply biased estimates.

The characteristics of the estimated sample were disaggregated between the census situation (Urban and Rural) and the gender of the individual. The sample (Note 2) is composed by 185,836 observations in which there are 86,241 urban males, 74,026 urban females, 15,932 and 9,637 rural males and females, respectively.

The survey gathers detailed information about the demographic characteristics of the population, education, migration, housing conditions, family income, among others. As for the variables, the condition of individuals in the job market in the situation of involuntary unemployment (dummy variable) was considered as the dependent variable. Two questions are used to distinguish voluntary and involuntary unemployment. For each potential worker, the individual asked if he or she has been actively searching for a job in the last 4 weeks and if he or she is ready to begin working within the next two weeks. The independent variables are:

\begin{tabular}{cc}
\hline Explanatory Variables (Note 3,4) & Reference \\
\hline rnordeste & Northeast region dummy variable \\
rsudeste & Southeast region dummy variable \\
rcentro_oeste & Center-West region dummy variable \\
rsul & South region dummy variable \\
dum_urbano1 & Dummy variable of census situation, 1 if rural, 0 otherwise \\
dum_cor2 & Dummy variable for race, 1 if white, 0 otherwise \\
sexo & Dummy variable for gender, 1 if male, 0 otherwise \\
idade & Age \\
idade2 & Age squared \\
solteiro & Number of children \\
nfilhos & Pummy variable for Marital Status, 1 if single, 0 otherwise \\
migr & Years of schooling \\
anoest & Yoars of schooling squared \\
anoest2 & Education dummy variable, 1 if "without schooling" \\
dum_EDUC1 & Education dummy variable, 1 if "1 to 3 years of schooling" \\
dum_EDUC2 & Education dummy variable, 1 if "4 to 7 years of schooling" \\
dum_EDUC3 & Education dummy variable, 1 if " 8 to 10 years of schooling" \\
dum_EDUC4 & Education dummy variable, 1 if "11 to 14 years of schooling" \\
dum_EDUC5 &
\end{tabular}

Source: Prepared by the authors using data from the 2015 PNAD.

The estimate focused on individuals characterized as being involuntarily unemployed and aged 14 years old or older. In this context, an individual is involuntarily unemployed if he or she is between the ages of 14 and 65 , and actively searching for a job in the last 4 weeks, and if he or she is ready to begin working within the next two weeks. It should be emphasized that the model used in this research will obtain estimates of the coefficients and elasticities of the measure of involuntary unemployment measured by the variables presented in this subsection.

\subsection{The Econometric Model}

According to Greene (2000), the logit model does not require the normality of the independent variables and the equality of covariance matrices, being similar to a multiple regression, because it does not have the power to 
incorporate nonlinear effects (Hair, 1998). According to Hosmer and Lemoshow (1989), the logistic regression technique has become a standard method of regression analysis for dichotomously measured variables. An advantage of the logistic regression is its probabilistic approach. According to Hower and Lemoshow (1989), the logistic regression aims to find the most appropriate relationship between the dependent variable and a set of explanatory variables.

It is considered that the error term, $\varepsilon_{i}$, has a logistic distribution. Therefore, the conditional probability function of the logit model is given by:

$$
\operatorname{Pr}\left(y_{i}=1 \mid x_{i}\right)=G\left(x_{i}\right)=\frac{\exp \left(x_{i} \beta\right)}{1+\exp \left(x_{i} \beta\right)}
$$

Where $\mathrm{G}($.$) is the cumulative of a logistic distribution density function, y_{i}$ has value 1 if the individual is involuntarily unemployed, and 0 if otherwise; $x_{i}$ are a vector of explanatory variables related to individual factors, demoFigurey and place of residence.

A binary choice model is often used in applied microeconomics. In particular, its recursive form is useful when estimating the effect of a dummy variable on a binary result. The estimation is performed by means of the maximum likelihood estimator. This estimator selects estimates of the unknown parameters in order to maximize the value of the maximum likelihood function (GREENE, 2012). For the model used here, its function is given by:

$$
L(\beta)=\sum_{i}^{N}\left\{y_{i} \ln \left(\frac{\exp \left(x_{i} \beta\right)}{1+\exp \left(x_{i} \beta\right)}\right)+\left(1-y_{i}\right) \ln \left(\frac{1}{1+\exp \left(x_{i} \beta\right)}\right)\right\}
$$

When working with a binary (or any other non-linear) model, the explanatory coefficients do not measure the true marginal effects of these variables, as is done when using the Ordinary Least Squares estimator. Since the logit model is nonlinear, as G (.) is a nonlinear function, the absolute value of the coefficients has no economic significance, and only information about the signal and its statistical significance is used. However, to interpret the economic significance of the explanatory variables, it is necessary to calculate the marginal effects of the estimated coefficients. Lorg and Freese (2006) argue that, in logistic regressions, marginal effects measure discrete modifications in a more informative way, thus, it is possible to have a more precise explanation of the effects of each endogenous variable. To analyze the quantitative impacts generated from the variation of an explanatory variable, we use the average marginal effect of the logit model, defined by:

$$
\frac{1}{N} \sum_{i} \frac{\exp \left(x_{i}^{\prime} \beta\right)}{1+\exp \left(x_{i}^{\prime} \beta\right)} \frac{1}{1+\exp \left(x_{i}^{\prime} \beta\right)} \beta
$$

The average marginal effects feature the advantage of allowing the analysis of the quantitative implications related to the estimated coefficients. It is also worth mentioning that it is of particular interest the examination of potentially policy-friendly variables, such as education and location, that alter the probability of unemployment in different ways.

In order to use the most appropriate model, some tests were done. The Hosmer-Lemeshow Goodness-of-fit test proves whether the proposed model can adequately explain what is observed through the distances between the adjusted probabilities and the probabilities observed. According to Hair (1998), a good model fit is indicated by a non-significant chi-square value. In order to corroborate with the first test, the likelihood ratio test is used where, according to Fávero (2014), the test is analyzed in similar fashion to the linear regression F test, but using a chi-square distribution statistic to analyze the significance of the model. Lastly, we considered the Receiver Operating Characteristic (ROC) curve, which measures the ability of the model to discriminate the categories of the dependent variable. After all of these tests of robustness, the most appropriate model to be used in this work is the Logit model.

\section{Results and Discussion}

In order to identify the microeconomic constraints that have an impact on involuntary unemployment in Brazil, a probabilistic model was used for Brazil as a whole, and the Urban and Rural areas separately, in order to avoid inconsistent results, given the magnitude of the country and the specificities found in its environment. The results extracted from the 2015 PNAD are presented and analyzed in the course of this section.

Table 1 and Annex A.1 present the main statistics used in this work. It can be observed that the majority of those individuals which are involuntarily unemployed in Brazil are male, with an average age of 37.3 years and non-white, mostly unmarried. As for the size of the family, the average number of children is around 3.5 children, with a relatively high educational level, the largest portion having between 11 and 14 years of schooling, but on 
average having 10 years of formal education. From Annex A.1, it can be seen that both men and women in involuntary unemployment in the urban area have an average of 37 years of age, are non-whites and single. When focusing in the rural area of the country, the result differs for women, who are on average 38 years old and most are married. Those individuals who reside in the urban areas of Brazil have a higher level of education, with more years of schooling, being mostly 11 to 14 years of formal education, while for those residing in rural areas, the majority of men have a maximum of 7 years of education, with women who live in the rural areas having more years of schooling - almost $30 \%$ have 11 to 14 years of formal education. Also, according to the data in Annex A.1, men have fewer years of schooling, on average one year less than women.

Table 1. Descriptive statistics for the estimation sample - Brazil

\begin{tabular}{|c|c|c|c|c|c|}
\hline Covariates & Observations & Mean & Standard Deviation & Maximum & Minimum \\
\hline Sex & 185.836 & 0.5500 & 0.4974 & 0 & 1 \\
\hline Age & 185.836 & 37.3 & 12.7680 & 14 & 65 \\
\hline $\mathrm{Age}^{2}$ & 185.836 & 1554.975 & 999.3148 & 194 & 4225 \\
\hline Race/White & 185.836 & 0.4469 & 0.4971 & 0 & 1 \\
\hline Marital Status (Single) & 185.836 & 0.5259 & 0.4993 & 0 & 1 \\
\hline Number of children & 185.836 & 3.5960 & 1.5855 & 1 & 18 \\
\hline No schooling & 185.836 & 0.0509 & 0.2198 & 0 & 1 \\
\hline 1 to 3 years of schooling & 185.836 & 0.0597 & 0.2370 & 0 & 1 \\
\hline 4 to 7 years of schooling & 185.836 & 0.1889 & 0.3914 & 0 & 1 \\
\hline 8 to10 years of schooling & 185.836 & 0.1783 & 0.3828 & 0 & 1 \\
\hline 11 to 14 years of schooling & 185.836 & 0.3860 & 0.4868 & 0 & 1 \\
\hline years of schooling & 185.836 & 10.0915 & 4.1568 & 1 & 16 \\
\hline years of schooling ${ }^{2}$ & 185.836 & 119.1185 & 77.4309 & 1 & 256 \\
\hline Rural Area & 185.836 & 0.1434 & 0.3505 & 0 & 1 \\
\hline Migrant & 185.836 & 0.4292 & 0.4949 & 0 & 1 \\
\hline Northeast & 185.836 & 0.2567 & 0.4368 & 0 & 1 \\
\hline Southeast & 185.836 & 0.4355 & 0.4958 & 0 & 1 \\
\hline Center-West & 185.836 & 0.0786 & 0.2691 & 0 & 1 \\
\hline South & 185.836 & 0.1498 & 0.3569 & 0 & 1 \\
\hline
\end{tabular}

Source: Prepared by the authors using data from the 2015 PNAD.

In terms of the different regions of the country, Figure 1 shows, in percentage points, the relationship between men and women in situations of involuntary unemployment for the urban and rural areas of the regions of Brazil. It can be observed that the Southeast region, followed by the Northeast, presents the highest percentage points of unemployed individuals, considering the urban areas. For those individuals in the rural areas, the order is reversed, with the Northeast having the highest number of unemployed people, followed by the Southeast region. It is noteworthy that, except for the North region of the country, all other regions had, in proportional terms, more women in involuntary unemployment than men, especially in the Southeastern region and the Northeastern region of Brazil, both of which are more representative of involuntary unemployment.

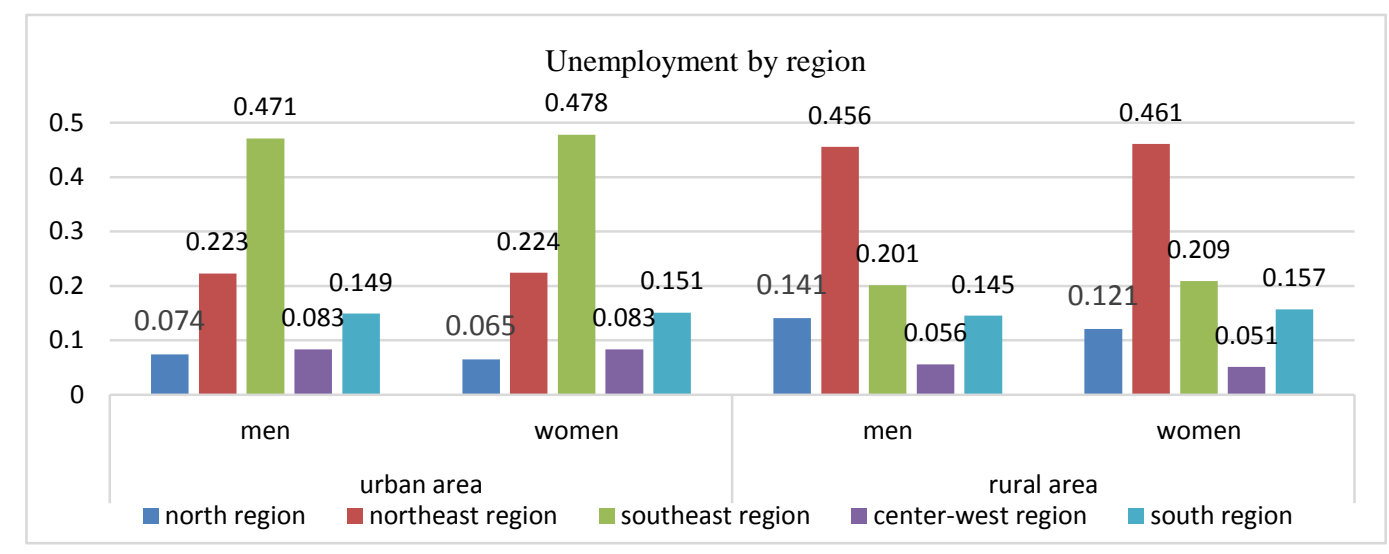

Figure 1. Involuntary unemployment between men and women by region and area

Source: Prepared by the authors using microdata from the 2015 PNAD. 
In order to define which binary choice model will be adopted, estimates and the selection of several combinations of variables and models (Logit and Probit) were performed. Table 2 shows the results of the most adequate fit obtained for the two models. According to the results presented, we see a similarity, with a small advantage for the Logit model, which featured the best results for the Pseudo $\mathrm{R}^{2}$, ROC curve and for the Hosmer-Lemeshow test, with a p-value greater than 0.26 , thus we do not reject the null hypothesis that there is an association between the observed and predicted values and, consequently, the model can be considered as having a good fit.

Table 2. Selection criteria of the binary choice model, Probit and Logit models

\begin{tabular}{clc}
\hline Criteria & \multicolumn{2}{c}{ Coefficients - Binary Choice Models } \\
\cline { 2 - 3 } & Probit & Logit \\
\hline Pseudo $R^{2}$ & 0.1275 & 0.1279 \\
Likelihood Ratio & 0.0001 & 0.0001 \\
Hosmer-Lemeshow Goodness-of-fit & 0.0000 & 0.2639 \\
ROC (Receiver Operating Characteristic) Curve & 0.7656 & 0.7655 \\
\hline
\end{tabular}

Source: Prepared by the authors using data from the 2015 PNAD.

As can be observed in the results presented in Table 3, the coefficients of the marital status, number of children, years of schooling, as well as the Northeast region variables, are positive and statistically significant. The age variable was also statistically significant with a negative sign, the same being observed with gender, being from rural areas and living in regions other than the Northeast. Correlating these initial results with those obtained by Boer (2015), we see that the unemployment issue seems to be less frequently a problem for non-single individuals. Sackey and Osei (2006) argue that younger people are more prone to involuntary unemployment due to the fact that they have fewer skills compared to older people. According to Anyanwu (2013), a number of reasons can be used to justify this result, including the fact that younger workers tended to be easier and less expensive to dismiss than older workers. Monte (2011) shows that the reserve wages of younger individuals who are unemployed are on average higher, such evidence being possibly related to the opportunity cost that permeates the decision between studying and working. Unemployment is also identified as an urban phenomenon, which is confirmed in the literature by Dickens and Lang (1995) and Boateng (1994).

It was found, therefore, that younger men in the Southeast, Center-west and South regions of Brazil, who live in rural areas and who are more educated, tend to be less in involuntary unemployment. However, these estimated parameter values do not give us precise information on the effects or elasticities. Therefore, estimating the coefficients of the Logit model is also necessary to analyze the marginal effects.

Table 3. Logit model estimation and average marginal effects - Brazil - Rural and Urban areas

\begin{tabular}{ccccccc}
\hline \multirow{2}{*}{ Variables } & \multicolumn{5}{c}{ Logit Model Regression } \\
\cline { 2 - 7 } & \multicolumn{3}{c}{ Coefficients } & \multicolumn{3}{c}{ Average Marginal Effects } \\
\hline \multirow{3}{*}{ Gender (Male) } & Brazil & Rural & Urban & Brasil & Rural & Urban \\
& -0.822 & -0.986 & -0.807 & -0.036 & -0.014 & -0.040 \\
Age & $(0.019)$ & $(0.000)$ & $(0.000)$ & $(0.000)$ & $(0.000)$ & $(0.000)$ \\
& -0.203 & -0.108 & -0.209 & -0.008 & -0.001 & -0.010 \\
Age ${ }^{2}$ & $(0.004)$ & $(0.000)$ & $(0.000)$ & $(0.000)$ & $(0.000)$ & $(0.000)$ \\
& 0.002 & 0.000 & 0.000 & 0.001 & 0.000 & 0.000 \\
Race (white) & $(0.000)$ & $(0.059)$ & $(0.000)$ & $(0.000)$ & $(0.078)$ & $(0.000)$ \\
& 0.041 & -0.112 & -0.035 & -0.002 & -0.001 & -0.001 \\
Marital Status (single) & $(0.021)$ & $(0.220)$ & $(0.108)$ & $(0.001)$ & $(0.209)$ & $(0.106)$ \\
& 0.309 & 0.354 & 0.303 & 0.014 & 0.005 & 0.015 \\
Number of children & $(0.025)$ & $(0.001)$ & $(0.000)$ & $(0.008)$ & $(0.001)$ & $(0.000)$ \\
& 0.069 & 0.050 & 0.072 & 0.003 & 0.000 & 0.003 \\
No schooling & $(0,005)$ & $(0.007)$ & $(0.000)$ & $(0.007)$ & $(0.010)$ & $(0.000)$ \\
& 1.077 & 1.400 & 1.043 & 0.047 & 0.020 & 0.052 \\
1 to 3 years of schooling & $(0.204)$ & $(0.058)$ & $(0.000)$ & $(0.005)$ & $(0.060)$ & $(0.000)$ \\
& 0.628 & 0.490 & 0.700 & 0.027 & 0.007 & 0.034 \\
\end{tabular}




\begin{tabular}{|c|c|c|c|c|c|c|}
\hline 4 to 7 years of schooling & $\begin{array}{c}0.387 \\
(0.122)\end{array}$ & $\begin{array}{c}0.409 \\
(0.459)\end{array}$ & $\begin{array}{c}0.427 \\
(0.001)\end{array}$ & $\begin{array}{c}0.017 \\
(0.003)\end{array}$ & $\begin{array}{c}0.006 \\
(0.472)\end{array}$ & $\begin{array}{c}0.021 \\
(0.000)\end{array}$ \\
\hline 8 to 10 years of schooling & $\begin{array}{c}0.339 \\
(0.103)\end{array}$ & $\begin{array}{c}0.423 \\
(0.384)\end{array}$ & $\begin{array}{c}0.362 \\
(0.001)\end{array}$ & $\begin{array}{c}0.014 \\
(0.001)\end{array}$ & $\begin{array}{c}0.006 \\
(0.397)\end{array}$ & $\begin{array}{c}0.018 \\
(0.001)\end{array}$ \\
\hline 11 to 14 years of schooling & $\begin{array}{c}0.190 \\
(0.077)\end{array}$ & $\begin{array}{c}0.713 \\
(0.063)\end{array}$ & $\begin{array}{c}0.181 \\
(0.022)\end{array}$ & $\begin{array}{c}0.008 \\
(0.000)\end{array}$ & $\begin{array}{c}0.010 \\
(0.073)\end{array}$ & $\begin{array}{c}0.009 \\
(0.021)\end{array}$ \\
\hline years of schooling & $\begin{array}{c}0.197 \\
(0.039)\end{array}$ & $\begin{array}{c}0.164 \\
(0.226)\end{array}$ & $\begin{array}{c}0.176 \\
(0.000)\end{array}$ & $\begin{array}{c}0.008 \\
(0.001)\end{array}$ & $\begin{array}{c}0.002 \\
(0.243)\end{array}$ & $\begin{array}{c}0.008 \\
(0.000)\end{array}$ \\
\hline years of schooling ${ }^{2}$ & $\begin{array}{l}-0.009 \\
(0.001)\end{array}$ & $\begin{array}{l}-0.003 \\
(0.556)\end{array}$ & $\begin{array}{l}-0.008 \\
(0.000)\end{array}$ & $\begin{array}{l}-0.001 \\
(0.001)\end{array}$ & $\begin{array}{l}-0.000 \\
(0.585)\end{array}$ & $\begin{array}{l}-0.000 \\
(0.000)\end{array}$ \\
\hline Rural area & $\begin{array}{l}-1.090 \\
(0.040)\end{array}$ & - & - & $\begin{array}{l}-0.048 \\
(0.001)\end{array}$ & - & - \\
\hline Migrant & $\begin{array}{l}-0.156 \\
(0.020)\end{array}$ & $\begin{array}{c}0.087 \\
(0.289)\end{array}$ & $\begin{array}{l}-0.177 \\
(0.000)\end{array}$ & $\begin{array}{l}-0.007 \\
(0.000)\end{array}$ & $\begin{array}{c}0.001 \\
(0.289)\end{array}$ & $\begin{array}{l}-0.008 \\
(0.000)\end{array}$ \\
\hline Northeast region & $\begin{array}{c}0.049 \\
(0.029)\end{array}$ & $\begin{array}{c}0.554 \\
(0.000)\end{array}$ & $\begin{array}{l}-0.004 \\
(0.892)\end{array}$ & $\begin{array}{c}0.002 \\
(0.001)\end{array}$ & $\begin{array}{c}0.008 \\
(0.000)\end{array}$ & $\begin{array}{l}-0.000 \\
(0.892)\end{array}$ \\
\hline Southeast region & $\begin{array}{l}-0.102 \\
(0.029)\end{array}$ & $\begin{array}{c}0.512 \\
(0.000)\end{array}$ & $\begin{array}{l}-0.150 \\
(0.000)\end{array}$ & $\begin{array}{l}-0.004 \\
(0.001)\end{array}$ & $\begin{array}{c}0.007 \\
(0.000)\end{array}$ & $\begin{array}{l}-0.007 \\
(0.000)\end{array}$ \\
\hline Center-West region & $\begin{array}{l}-0.428 \\
(0.040)\end{array}$ & $\begin{array}{l}-0.090 \\
(0.648)\end{array}$ & $\begin{array}{l}-0.469 \\
(0.000)\end{array}$ & $\begin{array}{l}-0.019 \\
(0.001)\end{array}$ & $\begin{array}{l}-0.001 \\
(0.643)\end{array}$ & $\begin{array}{l}-0.023 \\
(0.000)\end{array}$ \\
\hline South region & $\begin{array}{l}-0.574 \\
(0.038)\end{array}$ & $\begin{array}{l}-0.022 \\
(0.892)\end{array}$ & $\begin{array}{l}-0.628 \\
(0.000)\end{array}$ & $\begin{array}{l}-0.025 \\
(0.001)\end{array}$ & $\begin{array}{l}-0.000 \\
(0.890)\end{array}$ & $\begin{array}{l}-0.031 \\
(0.000)\end{array}$ \\
\hline Number of observations & 185.836 & 25.569 & 160.267 & 185.836 & 25.569 & 160.267 \\
\hline Prob $>$ Chi2 2 & 0.0000 & 0.0000 & 0.0000 & 0.0000 & 0.0000 & 0.0000 \\
\hline Pseudo $R^{2}$ & 0.1279 & 0.1535 & 0.1211 & - & - & - \\
\hline Log maximum Pseudo- likelihood & -40707.5 & -3044.7 & -37505.0 & - & - & - \\
\hline
\end{tabular}

Source: Prepared by the authors.

Long (1997) says that in regressions of logistic models, marginal effects measure discrete modifications in a more informative way, allowing a more precise explanation of the effects of each explanatory variable.

The effect of race on the probability of involuntary unemployment confirms the patterns observed in other works. Non-whites are more likely to be unemployed than whites, suggesting racial discrimination in the hiring practices of employers. The probability of unemployment decreases with age, but at a decreasing rate, to some extent, as can be seen next to the result of the Age squared variable. More experienced workers can be protected against competition from young workers by laws or market institutions or by firm-specific human capital. Alternatively, young people may have a greater chance of being involuntarily unemployed because of their greater degree of job mobility, corroborating results found by the Cinterfor/ILO (1997) (Note 5) and Silva (2001).

With the results of the average marginal effects obtained, it can be observed that the influence of the individual being male is only slightly greater in the urban areas than in the rural environment, having influence in four points in the probability of the individual not being in the situation of involuntary unemployment. As for the age variable, involuntary unemployment seems to have the greatest impact on urban dwellers, a result which may indicate a possible migration of young people and/or informal work. The Race variable is significant when considering Brazil as a whole, showing a small impact on the probability of the individual not being involuntarily unemployed, however, analyzing separately the rural and urban areas, the variable is shown to be not statistically significant.

The relationship between qualification and unemployment in Brazil appears to be shaped as an inverted $\mathrm{U}$, thus supporting what Camargo and Reis (2005), Fernandes and Pichetti (1999), Barros (1997) and Amoedo (1994) found for different periods of analysis in Brazil. The incidence of involuntary unemployment decreases dramatically with increased education. For example, having between 11 and 14 years of schooling reduces the prevalence of a person remaining unemployment to a probability of almost zero. The marginal effect of having between 11 and 14 years of education is about 0.8 percentage points, whereas for unschooled individuals the probability of involuntary unemployment is 4.7 percentage points.

However, variables related to education are not statistically significant for the rural environment, only for the 
urban environment and for Brazil as a whole, having a considerable impact. It can be observed that with increased years of education, individuals tend to decrease the likelihood of being involuntarily unemployed. Being a resident of the Northeast and Southeast regions of Brazil implies a positive and statistically significant effect on involuntary unemployment, even with a marginal effect. On the other hand, being a resident of the South and Center-West regions will have a negative effect on the urban dwellers.

The number of children can increase involuntary unemployment, especially for women, due to the greater responsibility and given the less flexible hours. In the alternative model (Note 6), the positive effect of the number of children on the probability of involuntary unemployment is about twice as high for women as for men, following what is suggested by Blendell (1987), Hogan (2004) and Laroque and Salanie (2002).

Regarding the "Marital Status" variable, the fact that the individual is single increases the chances of involuntary unemployment, possibly due to the notion of economic responsibility weighing more heavily on married individuals. Bargain (2010) and Henk-Wim (2018) came to similar results in their studies, where they show that the largest parcels of the unintentionally unemployed are unmarried individuals. The positive effect of being single on the probability of unemployment comes if it is taken as a signaling quality that employers use to ration jobs. Another explanation is that with the lesser economic responsibilities of individuals who are single, they may tend to have higher reserve wages.

Being a non-migrant implies a substantially greater risk of being unemployed. A migrant individual is about -0.7 points less prone to unemployment. Individuals from all regions except the Northeast are significantly less likely to be unemployed.

In short, the results on the explanatory variables are consistent with the fact that the job market for more qualified workers is more restrictive. Also, the rural environment differs from the urban environment regarding the conditions of involuntary unemployment, probably due to its own differentiated structure.

\section{Concluding Remarks}

This work aimed at analyzing involuntary unemployment in Brazil using microdata from the 2015 PNAD, which is the National Household Sample Survey, an annual database compiled by the IBGE, the Brazilian Institute of Geography and Statistics. The objective was both to analyze what factors could cause involuntary unemployment in the country, as well as to try and perceive if any form of discrimination in terms of employment could be determined.

Involuntary unemployment in Brazil, observed from the microeconomic point of view, gives us results compatible with the rest of the world, both when comparing to developed and developing countries. Analyzing the four major regions of Brazil, excluding the more sparsely populated North region, the results show that, among the Brazilian regions, there are two regions which are particular, being the Southeast and Northeast, for having the highest levels of involuntary unemployment in the urban areas, and featuring more women than men living in that situation. The same result was, as expected, found when analyzing the Race variable. Non-whites are more likely to be unemployed than whites, also possibly confirming a racial bias and discriminatory practice in terms of employment.

Following what was evidenced through the results of the application of the Logit model, it is concluded that men have a lower propensity to involuntary unemployment, with elasticity (in module) of $3.6 \%$. Young people tend to be in involuntary unemployment more than more experienced individuals, possibly because of professional experience, or even because the reserve wages of younger people being higher, generating a curve in the form of an inverted $\mathrm{U}$. The ratio of involuntary unemployment to number of children is positively inclined, especially for women, given the usual greater responsibility attributed to them, which makes them less have fewer flexible hours.

Concerning the individual's Marital Status, it is concluded that being single increases the likelihood of involuntary unemployment, something which is possibly linked to an entrepreneurial perception which lingers that single people tend to have a lower economic responsibility, complementing the fact that young people have a greater probability of being unemployed. Thus, women, especially if they have children, and single people are possibly being discriminated against in the Brazilian job market.

Considering the migrants which move from one state to the other in the country, these tend to suffer less from involuntary unemployment, migrating between the federative units of Brazil, and frequently moving when employment is already guaranteed, in addition to the fact that the migration usually indicates that the state of origin was passing through a disadvantageous moment in the job market.

Furthermore, it was found that, despite the existence of some conditions that corroborate involuntary 
unemployment for the urban and rural areas, most of the covariates studied only present significance in one of the two environments, or will be statistically significant but with opposite signs, indicating that while for an area the variable can imply a decrease in the probability of involuntary unemployment, for the other, the covariate would end up generating a greater probability of involuntary unemployment.

\section{References}

Alvaro, J. L. (1992). Desempleo y bienestar psicológico. Madrid: Siglo XXI.

Anyanwu, J. C. (2013). Characteristics and Macroeconomic Determinants of Youth Employment in Africa. African Development Review, 107-129. https://doi.org/10.1111/j.1467-8268.2013.12019.x

Araújo, J. P. F., \& Antigo, M. F. (2016). Desemprego e Qualificação de Mão de Obra no Brasil. Revista de Ecoomia Contemporânea. https://doi.org/10.1590/198055272025

Bargain, O., Caliendo, M., Haan, P., \& Orsini, K. (2010). Marking work pay in a rationed labor market. Journal of Population Economics, 323-351. https://doi.org/10.1007/s00148-008-0220-9

Bargain, O., Orsini, K., \& Peichl, A. (2014). Comparing Labor Supply Elasticities in Europe and The United States: New Results. The Journal of Human Resources, 49, 723-838. https://doi.org/10.3368/jhr.49.3.723

Barros, R., Camargo, J. M., \& Mendonça, R. (1997). Estrutura do desemprego no Brasil. Texto para Discussão do IPEA, n. 478.

Becker, S. G. (1975). Human capital: a theoretical and empirical analysis, with special reference to education (2nd ed.). Nova York: Columbia University.

Blundell, R., \& Shephard, A. (2012). Employment, Hours of Work and the Optimal Taxation of Low-Income Families. The Review of Economic Studies, 79(2), 481-510. https://doi.org/10.1093/restud/rdr034.

Blundell, R., Ham, J., \& Meghin, C. (1987). Unemployment and female labour supply. The Economic Journal, 97, 44-64. https://doi.org/10.2307/3038229

Boer, H. W. (2015). A Structural Analysis of Labour supply and Involuntary Unemployment in the Netherlands. CPB Netherlands Bureau for Policy Analysis Discussion Paper.

Camargo, J. M., \& Reis, M. C. (2005). Desemprego: o custo da desinformação. Revista Brasileira de Economia, 59. https://doi.org/10.1590/S0034-71402005000300003

Christiano, L. J., Trabandt, M., \& Walentin, K. (2010). Involuntary Unemployment and the Business Cycle. European Central Bank Working Papers. https://doi.org/10.3386/w15801

Cinterfor/Oit. (1997). El empleo y la capacitación para el empleo de jóvenes en América Latina. Montevideu.

Dickens, W. T., \& Lang. K. (1995). An Analysis of the Nature of Unemployment in Sri Lanka. The Journal of Development Studies, 31(4), 620-636. https://doi.org/10.1080/00220389508422381

Fernandes, R. A. S., Lima, J. E., \& Santos, C. M. (2008). A exclusão social de mulheres jovens, com idade entre 15 a 24 anos, no mercado de trabalho no Brasil. Revista de Economia e Administração, 7(2), 125-136. https://doi.org/10.15628/holos.2017.4078

Fernandes, R., \& Picchetti, P. (1999). Uma análise da estrutura do desemprego e da inatividade no Brasil metropolitano. Pesquisa e Planejamento Econômico, 29(1), 87-112.

Greene, W. H. (2012) Econometric Analysis (7th ed.). Nova York: Pearson.

Hair. Jr. J. F. et al. (1998). Multivariate Data Analysis with Readings. Englewood Cliffs, New jersey: Prentice-Hall.

Hogan, V. (2004). The welfare cost of taxation in a labor Market with unemployment and non-participation. Labour Economics, 11, 395-413). https://doi.org/10.1016/j.labeco.2004.01.005

Hosmer, D. W., \& Lemeshow, S. (1989). Applied Logistic Regression. John Wiley e Sons. Nova York. https://doi.org/10.1002/sim.4780100718

Kato, J. M., \& Ponchirolli, O. (2002). O desemprego no Brasil e seus desafios éticos. Revista da Fae, 5(3), 87-97.

Keane, M., \& Moffitt, R. (1998). A Structural Model of Multiple Welfare Program Participation and Labor Supply. Internacional Economic Review, 39, 553-589. https://doi.org/10.1016/S1573-4420(02)80013-1

Kingdon, G. G., \& Knight, J. (2004). Unemployment in South Africa: The Nature of the Beast. World 
Development, 32, 391-408. https://doi.org/10.1016/j.worlddev.2003.10.00

Laroque, G., \& Salanie, B. (2002). Labour Market institutions and employment in France. Journal of Applied Econometrics, 17, 25-48. https://doi.org/10.1002/jae.656

Layard, R., Nickell, S., \& Jackman, R. (1991). Unemployment macroeconomic performance and the labour market. Oxford: Oxford University.

Lindbeck, A., \& Snower, D. J. (1987). Cooperation, Harassment and Involuntary Unemployment: An Insider-Outsider Approach. Development Research Department Discussion Paper, World Bank.

Long, J. S., \& Freese, J. (2006). Regression Models for Categorical Dependent Variables Using Stata (2nd ed.). Stata Press.

Mendonça, T. G., Lima, J. R., \& Lírio, V. S. (2012). Determinantes da inserção de mulheres jovens no mercado de trabalho nordestino. Revista Econômica do Nordeste, 43(4).

Mochon, F., \& Troster, R. L. (1994). Introdução à economia. São Paulo, Makron Books.

Monte, P. A., Ramalho, H. M. B., \& Pereira, M. L. (2011). O salário de reserva e a oferta de trabalho: Evidências para o Brasil. Economia Aplicada, 15(4), 613-639. https://doi.org/10.1590/S1413-80502011000400005

Rossi, T., \& Oliveira, E. A. A. Q. (2005). A questão do desemprego no Brasil. IX Encontro Latino Americano de Iniciação Científica e V Encontro Latino Americano de Pós-Graduação.

Sackey, H. A., \& Osei, B. (2006). Human Resource Underutilisation in an Era of Poverty Reduction: An Analysis of Unemployment and Underemployment in Ghana. African Development Review, 18(2), 221-247. https://doi.org/10.1111/j.1467-8268.2006.00140.x

Sampaio, A. V. (2012). Estrutura do mercado de trabalho metropolitano na Região Sul do Brasil, em 1995 e em 2005. Nova Economia, 22(1), 85-115. https://doi.org/10.1590/S0103-63512012000100003

Santos, C. M. S., Leal, F. D., \& Fernandes, R. A. S. (2010). A exclusão social de mulheres jovens, com idade entre 15 a 24 anos, no mercado de trabalho mineiro. In SEMINARIO SOBRE A ECONOMIA MINEIRA. Diamantina. Anais... Belo Horizonte: UFMG/CEDEPLAR.

Silva, N. D. V. (2001). Jovens brasileiros: o conflito entre estudo e trabalho e a crise de desemprego (p. 131). Piracicaba, Tese (Doutorado) ESALQ/USP.

Silvia, P. L. N., Pessoa, D. G. C., Lila, M. F. (2002). Análise estatística de dados da pnad: Incorporando a estrutura do plano amostral. Ciência Saúde Coletiva, 7, 659-670. https://doi.org/10.1590/S1413-81232002000400005

Van Soest, A. (1995). Structural models of family labor supply: A discrete choice approach. Journal of Human Resources, 30, 63-88. https://doi.org/10.2307/146191

Wooldridge, M. J. (2003). Introductory Econometrics: A Modern Approach (1st ed.). Mason: South-Western College Pub.

\section{Notes}

Note 1. It was decided to use the annual PNAD due to the lack of variables to compose the model in the continuous PNAD.

Note 2. Individuals characterized by involuntary unemployment.

Note 3. The North region of Brazil was removed from the sample to avoid perfect multicollinearity. The criterion for selecting the base region was the number of observations in each region.

Note 4. The level of education with "15 years of schooling or more" was withdrawn to avoid perfect multicollinearity. The decision criterion was the number of observations in this group.

Note 5. Available, in Spanish, at http://www.oitcinterfor.org/node/5785. Accessed on April, $13^{\text {th }} 2019$.

Note 6. The authors estimated an alternative model for men and women separately, in order to observe the impact of the number of children on the involuntary unemployment of both genders. 


\section{Appendix}

Explanatory variables in mean and proportional values

\begin{tabular}{lcccc}
\hline & \multicolumn{2}{c}{ Urban Area } & \multicolumn{2}{c}{ Rural Area } \\
\cline { 2 - 5 } & Male & Female & Male & Female \\
\hline Age & 37.34 & 37.03 & 37.86 & 38.24 \\
Age $^{2}$ & 1559.004 & 1523.628 & 1626.186 & 1631.591 \\
Race & 0.451 & 0.478 & 0.342 & 0.357 \\
Marital Status & 0.532 & 0.511 & 0.586 & 0.489 \\
Number of Children & 3.565 & 3.529 & 3.872 & 3.889 \\
No schooling & 0.043 & 0.029 & 0.157 & 0.102 \\
1 to 3 years of schooling & 0.052 & 0.034 & 0.169 & 0.140 \\
4 to 7 years of schooling & 0.192 & 0.143 & 0.318 & 0.283 \\
8 to 10 years of schooling & 0.196 & 0.163 & 0.166 & 0.164 \\
11 to 14 years of schooling & 0.393 & 0.445 & 0.169 & 0.256 \\
15 years or more of schooling & 0.124 & 0.187 & 0.019 & 0.055 \\
years of schooling & 10.147 & 11.125 & 6.593 & 7.836 \\
years of schooling & 118.756 & 138.320 & 59.586 & 80.032 \\
Number of Observations & 86.241 & 74.026 & 15.932 & 9.637 \\
\hline
\end{tabular}

Source: Prepared by the authors using data from the 2015 PNAD.

\section{Copyrights}

Copyright for this article is retained by the author(s), with first publication rights granted to the journal.

This is an open-access article distributed under the terms and conditions of the Creative Commons Attribution license (http://creativecommons.org/licenses/by/4.0/). 